\title{
THE LAST CASE
}

\author{
W. G. MORROW*
}

This is the story of the last appeal to go from Canada to the Judicial Committee of the Privy Council. The material contained in the reported decisions is interesting but it is hoped the reader will find that the story back of the reports is even more interesting.

\section{INTRODUCTION}

As any lawyer knows, some of the most interesting legal discussions take place outside the court room-over coffee. One such discussion stands out clearly in my mind. An amendment had just been passed by the Federal Government making the Supreme Court of Canada the final or ultimate Court of Appeal for Canadian cases.1 This would be in early December 1949. Some of us were lamenting that very few, if any, of our generation of lawyers would be able to say that they had appeared before the Privy Council-that great judicial body that had formed a direct link between the subject and the foot of the throne when it came to law, and no matter from what part of the Empire or of the Commonwealth. I can remember at law school Dean Weir time after time using the phrase "go to the foot of the throne for Justice". This was now to be denied to Canadians. I could, and do, appreciate the social and political reasons for the change and certainly think it has given our Supreme Court the opportunity to develop and mature that was hitherto denied it.. ${ }^{2}$ But to we young lawyers, as we then were, some of the romance in law now appeared to have disappeared. At the time I can remember remarking that it would be worth $\$ 5,000.00$ to me to be able to say I had argued a case in London, the heart of Empire and the source of our law. This is the story of how I was to spend $\$ 7,000.00$ of my own money to finance an appeal to the Privy Council.

A few days after the coffee talk an old client called at my office. He was Alvin M. Davis. ${ }^{3}$ With him were several other business men from Leduc, Millet and Wetaskiwin. Following the discovery of oil near Leduc by Imperial Oil Limited in 1947 many of the local business men had gone into the risky business of looking for black gold. Mr. Davis and his associates had formed a company called Ponoka-Calmar Oils, Limited, and were attempting to develop some untested leases they had acquired to the south of the Leduc oil field.

He handed me a Statement of Claim which showed Earl F. Wakefield Company as plaintiff and several defendants including Mr. Davis's own company. The action was for a total of $\$ 65,745.62$ based on two Mechanics Liens, and constituted cost of drilling an as yet incomplete well on one of the legal subdivisions forming part of Ponoka-Calmar's leases. Mr. Davis said he was confident that the various parties involved

- Of the Supreme Court of Alberta, Appellate Division.

1. An Act to Amend the Supreme Court Act S.C. 1949 (2d Sesa.) c. 37.

2. During the hearings involving Justice Landreville, the late Hon. Ivan Rand remarked to me that great as the late Chief Justice Sir Lyman P. Duff was, he could never fully develop his talent because of the Privy Council and the necessity for Duff to always write his legal opinions in the light of what the higher tribunal might decide.

3. Alvin M. Davis, now deceased, was a retined auctioneer and farmer from Leduc, Alberta. He and his wife were two of the finest people I ever had as clients. 
would be able to reach a settlement but would I as a precaution file a defence to the action. This I did. Result-ten years of the most complicated litigation one could ever imagine.

I filed a Statement of Defence in which among other things the validity in itself of the mechanics liens filed by the Wakefield Company was raised.

In simple terms the factual situation at this time was as follows. Petroleum and natural gas leases had been obtained, covering 160 acres in Section 21, Township 49, Range 26, West of the Fourth Meridian, Alberta. One-half of the land acquired, some 80 acres, or two drilling sites, were leased from Harry Spilak, an additional legal subdivision had been acquired from Mike Szpilak. These leases which contained commitments to drill had been assigned by the lessees, Mr. Davis's associates, to Ponoka-Calmar Oils Limited. The remaining portion had been leased by Mary Chubocka to American Leduc Petroleums Limited. These two companies had in turn entered into an agreement, commonly referred to as a farm-out agreement, with a third company known as Oil City Petroleums (Leduc) Limited. The Oil City company was to receive the net proceeds of any petroleum products which might be found upon drilling in exchange for which they were to commence drilling and otherwise carry out the various commitments to the assignees and their lessors. The assignors were to receive a royalty from production and were to contribute certain monies towards each well required to be drilled. To handle royalties and monies a trust agreement was entered into by all of the above companies along with the Prudential Trust Company Limited as trustee. The drilling was to be done by Earl F. Wakefield Company and a drilling contract had been signed by this company and Oil City. It is interesting to note here that drilling had already been commenced and then suspended before the formal drilling contract was executed.

The Wakefield Company was to drill the first well, to be known as "Oil City No. 1" to a depth of 5,400 feet at a total cost of $\$ 50,000.00$.

Drilling actually started on September 23, 1949, and reached 2,570 feet when the driller suspended work because the bank had dishonoured payment of Oil City's deposit cheque. Liens to protect the cost of drilling to date and penalties were then filed by the driller to the total of $\$ 65,745.62$ and the proceedings referred to above were then begun in December.

This was generally the situation when I first came into the picture. My clients, as well as the officials of American Leduc Petroleums, next engaged in a series of negotiations in what turned out to be an abortive attempt to resolve the problem. However, a Mr. Duncan A. Campbell had in the meantime acquired the interest of Oil City Petroleums in the lands as well as shares in the company itself. He was now president and director of the company. Mr. Campbell was a man with considerable engineering experience and well versed in the oil exploration business. In the result Oil City Petroleums and Mr. Campbell together were able to persuade a new drilling company, Regent Drilling Company Limited, to complete the well as a producer on Legal Subdivision 7. This well was known as "Oil City No. 1 Well" and received tremendous press coverage with almost a full page of photographs.

It should be observed that two gentlemen by the names of George Harding and James MuMullen had originally sold some of the royalty interests which were identified with Oil City Petroleums and used the 
money so acquired for the commencement of drilling. It was essentially their remaining interests in the leases and in the company which Duncan A. Campbell had acquired.

One would have thought that the discovery of oil on the land would have solved all of the outstanding problems but rather it had the effect of compounding them. Because the land covered by the farm-out agreement was from three different owners and the respective leases had separate drilling commitments in the event of oil being found on adjoining land the discovery of oil had the effect of immediately triggering off the requirement of putting up further monies to drill more wells. But the money from the No. 1 well could not be used for the next drilling programme because the lien filed by the Wakefield Company had the effect of tying up this money until the legal issues could be resolved.

As production continued those persons who had call on shares of production began to worry whether their royalties would be secure.

In the mad scramble by creditors and interested claimants that followed, my instructions were to move for a receivership to protect the production so as to protect the royalties of my clients as well as others.

In the result a receivership was set up by $\mathbf{M r}$. Justice S. J. Shepherd on June 22, 1950. The Prudential Trust Company Limited 4 was appointed receiver of all the proceeds from the No. 1 well. This order provided for payment of operating costs first, royalty to the lessor Harry Spilak, and the balance to be held in a special trust account to the credit of this action. This receivership order with minor variations remained operative through the full life of the well.

Meanwhile, the problem of providing one offset well to protect the leases was occupying the attention of all parties. By letter dated September 21, 1950 Oil City Petroleums was advised by the Prudential Trust Company that, as required under the terms of the farm-out agreement, my clients had paid in $\$ 37,500.00$, their contribution towards the cost of drilling the first offset well.

By notice dated the 26th of October, 1950, my clients purported to terminate the agreement with Oil City Petroleums in all the lands except the legal subdivision upon which the No. 1 well had been drilled. The reasons put forward for cancellation can be briefly put as failure to drill or commence to drill the next well; failure or neglect to pay any amounts as they fell due; failure to pay off mechanics liens; and generally failure to comply with the terms of the farm-out agreement.

The events following the serving of this notice resulted in a new action being brought which went all the way to the Supreme Court of Canada. We leave the Wakefield Lien action for the moment, therefore, to follow the new proceedings.

\section{OIL CITY PETROLEUMS v. AMERICAN LEDUC PETROLEUMS}

By amended Statement of Claim filed in the Alberta Supreme Court on October 31st, 1950, M. E. Manning, as he then was, ${ }^{5}$ commenced action on behalf of Oil City Petroleums and Duncan A. Campbell against my clients for a declaration that the agreement had not been terminated by my notice of October 26th, 1950, or in the alternative for an Order that his

\footnotetext{
4. The Prudential Trugt was at its own request replaced part way through the litigation by the Toronto General Trust Corporation.

5. Now Justice M. E. Manning of the Trial Division of the Supneme Court of Alberta.
} 
clients were entitled to relief against forfeiture. We of course took issue. Ted Manning and I agreed on getting to trial as speedily as possible because of the danger of our leases being cancelled by the farmer-lessors.

At the trial before Chief Justice W. R. Howson, the Chief Justice of the Trial Division, the two issues of course were firstly whether the plaintiffs had commenced to drill the second well in time or whether in fact they had ever commenced to drill and secondly, if they were found to be in default, should they be relieved against forfeiture and be given a second chance. For my part, it was argued that the steps taken by the plaintiffs Oil City and Campbell were a mere ruse, a colourable attempt to make it appear that a well had been commenced to be drilled when in fact such was not the case. As to relief against forfeiture our defence was twofold, firstly that defaults in carrying out drilling commitments in petroleum leases were not normally relieved against because of the high risk in oil exploration and the danger that delays may result in potential lands being ruled out by nearby drilling; and secondly, that in any event the plaintiffs' lack of funds shown in respect of the first well pretty well ruled out any hope that they could carry out their commitments to drill a second well if given the opportunity.

At the trial evidence was called by both sides on the issues. For our side some very revealing photographs were introduced. In the result we clearly established that all that had been done was to bulldoze some ground, lay a few pipes, bring in a large metal storage tank and set it down nearby, and to have stuck a large diameter pipe into a hole in the ground. Duncan Campbell admitted in his discovery that this pipe, a length of casing, had been put in the hole to keep the hole from caving in. He admitted further, that it hadn't been cemented in and would have to be removed before they drilled further. There was no drilling rig on the site.

The case was heard November 13 and 14, 1950. The Chief Justice reserved judgment. He asked for written argument and promised to get out his judgment within three days of receiving written argument.

It is from here on that we get into some peculiar and unusual happenings.

Chief Justice Howson left Edmonton for Calgary to hear a very important mineral case, namely, Borys v. C.P.R.6 Remembering his promise to Ted Manning and myself, he apparently took the complete court file in our case with him. After the Borys trial, however, he appears to have felt so fatigued that he and his wife left on an extended motor tour in and around Arizona. I should observe here that the Chief Justice was known to be suffering from a heart condition.

While our Trial Judge was presumably enjoying a more salubrious climate, those left in Alberta and interested in the Oil City problem were becoming understandably restless. Oil business is by nature fast moving and law suits involving oil interests cannot normally be permitted to enjoy the more leisurely tempo of the ordinary type of case.

By early 1951 I found my clients back in my office carrying a termination notice which had been served on them by the solicitor for Mike Szpilak, one of our lessors. The complaint was our failure to get on with the next well. This was, of course, exactly what my people had feared all along and such possibility was one of our positions taken at the trial.

6. Borys v. Canadian Pacific Railway et al., (1951) 2 W.W.R. (N.S.) 145. 
It became necessary to take drastic steps if all was not to be lost.

I first attended upon Chief Justice G. B. O'Connor, Chief Justice of Alberta, and explained my problem. He advised me to locate Chief Justice Howson and indicated that he would then ask Howson to give judgment, whichever way it might be, over the long distance phone. I was to do this through the then Clerk of the Court, Alfred Simpson, Q.C. Ted Manning of course was kept in the picture although I gathered that his clients were not too unhappy at the delay.

When the Clerk attempted to find our Chief Justice he had quite a time. He first phoned the Judge's mother-in-law in Edmonton but even she had no idea of where he could be contacted other than somewhere in Arizona. Mr. Simpson then enlisted the help of the Attorney General of Arizona who alerted his state troopers to be on the lookout for the Chief Justice. For the next few days, daily reports came in from Arizona, generally to the effect that they had found the Judge's motel but he had just left or so on. Finally, they found that he had gone on to Califormia. At this point in time, Chief Justice O'Connor called a halt in the police effort and I was requested to bring on an application before him for directions.

On the hearing before Chief Justice O'Connor I outlined our dilemma. This motion came on before him on a Friday. He adjourned the application until 10:00 a.m. the next Monday morning, January 22, 1951. Just as we adjourned he told both Ted Manning and myself to come to court on Monday with the monies our respective clients were required to deposit for the next well. As I went out of the courtroom I warned my clients to have their money by Monday morning. They got it over the weekend, somehow, all $\$ 37,500.00$ of it.

The position we took was that if given permission we were prepared to commence drilling immediately to protect the lease. The other side opposed doing anything and as I recall, Mr. Manning indicated he was instructed to take the position that nothing should be done until Chief Justice Howson had rendered judgment.

During my twenty-five years as a lawyer in Alberta I had always found the Alberta Judges, for the most part, to be ready to take chances and innovate. There can be no doubt, though, that O'Connor outshone them all in inventiveness. This trait showed up in the present case. His Order was that my clients, through the Clerk, were to have the right to commence drilling on Legal Subdivision 2 immediately, without prejudice to the final outcome of the lawsuit except that my clients would be protected for monies expended.

I think that the willingness of my clients to put up their money and go ahead and the unwillingness of Mr. Manning's clients to assist or to take action themselves had considerable effect on the final outcome of the present proceedings, especially when the courts had to consider whether relief against forfeiture was justified.

As Manning and I were about to leave the Chief Justice's Chambers, O'Connor called us and with the usual twinkle in his eyes, said there was one more matter to be settled, namely who should advise the Clerk of the Court on engineering matters. Both Ted and I agreed that some such technical advice would be required.

"Well then," the Chief Justice said, "I have just the solution, a relative of mine is a petroleum engineer and is presently available for work. Would he be acceptable?" Ted and I looked at each other and smilingly 
agreed that this would be fine. It was understood that this gentleman would be paid on a percentage basis, based on expenditures, and that the Clerk would act on his instructions. Our engineer was Mr. A. L. Johnson and he did an excellent job for all concerned.

And so it was that the Clerk of the Court for the Supreme Court of Alberta was to drill his first oil well. It was an historic step. It had to be someone like Chief Justice O'Connor to take such a chance.

The story surrounding the drilling of this well is in itself a story. With my client's money the Clerk employed Earl F. Wakefield Company to drill the well. The driller ran into a tremendous amount of bad luck. Before the conclusion of drilling, the company ran into two "fishing" jobs7 and all kinds of other problems. I well remember when all parties sat down at a conference table to settle the outstanding differences in the cost of the well. Mr. Wakefield, an oilman from Kansas, was there himself. We were arguing over the high cost due to the fishing jobs. I will never forget his remarks, made in a casual manner and in a pleasant Kansas drawl, as he knocked off some $\$ 42,000.00$ from his bill. "Well this experience of ours up here in Canada hasn't been too happy to date, but that's the oil business." My last memory of him, a jolly red-faced man, strutting out of the room, cowboy hat on, and rolling an oversized cigar in his mouth.

Meanwhile there were developments in another direction. Chief Justice Howson had been back for some time but there was no sign of a judgment. Chief Justice O'Connor had apparently dropped him a note suggesting he get a judgment out but the recipient of the note did not take kindly to what he took as an unwarranted interference with the Trial Division. I got to know this from a casual remark passed on by O'Connor.

By this time the Provincial Legislature was in session. A delegation of my clients came in on Friday afternoon and advised that they were going down to the Legislative Building the next week to petition for Howson's impeachment. They had fire in their eyes and I knew they meant it. I found their threat distasteful even if to some extent justified. In addition I felt we had presented a winning case and didn't want to prejudice it. I pled with them to hold off for a few days and I would try to get some decision for them. They gave me a week.

I passed this on to Chief Justice O'Connor and he said he could do no more, but saw no harm in my seeing Howson himself. This I decided to do and told Mr. Manning. He didn't want to come with me-presumably figuring I would deserve any blast I might get. It took me several days to get up enough nerve to accost our trial judge and to think out my strategy as to the approach I should make.

Finally on the next Saturday I arranged an appointment with Chief Justice Howson. My opening gambit was that his delay had gotten matters in a mess. His immediate reply: "It's your own damn fault?"

Although I felt I knew what was to come next, I pretended surprise, and asked him how it was my fault.

He said: "You went over my head to another Judge."

With this at last in the open, I then went on to remind him of his promise to get out a judgment within a few days of our arguments being filed. I then described how he had instead taken off on a holiday. After I

7. "Fishing"- to seek to recover and draw forth from the well bore tools, cables, pipe, casing and rods which have become detached while in the well or which have been accidentally dropped into the well: Manual of Oil \& Gas Terms-Williams \& Meyers, p. 96. 
told him of the Clerk's efforts to locate him, how he hadn't even told his mother-in-law where he was going, and how that finally, in desperation I had sought Chief Justice O'Connor's help, he seemed to be somewhat mollified.

At this point I took my calculated chance and asked him for an immediate judgment. I said that if he didn't have time to consider the case now, I would be satisfied with an immediate judgment against my people so that I could then get on with an appeal.

The Chief Justice said he was sorry he had jumped me and that he would try to get his judgment out over the weekend. I found out later that he drove down to Wetaskiwin that afternoon to take an Inquest in respect of the Leduc explosion.

Late Sunday evening I received a most unexpected phone call at home. It was Chief Justice O'Connor. Apparently he had just heard from Howson at Wetaskiwin.

He said: "Bill, I have just had a call from Howson. He has given judgment your way. Knowing Howson's bad heart I think you should get the Clerk out of bed and have him go down to the Court House and record this judgment." I did this much to the discomfiture of Alfred Simpson.

On Monday morning Mr. Simpson, the Clerk, got a call from Wetaskiwin at 8 o'clock. He related it to me as follows:

This is Bill Howson. Since the President of the United States and everyone over hell's half acre wants this God-damned judgment you tell young Morrow to get the hell down here for it.

Anyone who knew Bill Howson would appreciate this as being his manner of speech on occasion and of course his reference to the President was to the Attorney General of Arizona.

When this message was passed on to me I immediately jumped into my car and sped to Wetaskiwin, arriving just after the Chief Justice had begun his explosion hearing. He adjourned after a few minutes and invited me to come to his chambers.

Chief Justice Howson and his wife were in his private chambers when I was ushered in. He had a big grin on his face and handed me a large bundle of rolled up paper kept in place by a strip of red inner tube. He said he had already arranged with the court reporters at Edmonton to type it out and I was to bring the typed copy back for signature as soon as it was prepared. The date was March 13, 1951.

When I examined this curious bundle back in my car it turned out to be some fourteen or fifteen sheets of ordinary scrap paper. What the judge had done was to take my written brief, cut out the portions where I had said "I submit, or it is submitted, etc." and written in their place, "I find, I conclude, etc." and then glued the remaining portions of my typed submission on the sheets as if he had written them. At the end of course he had written in pencil his final conclusion in favour of my client.

This was one of the most remarkable legal documents I have ever had the pleasure to see. My opponent, Ted Manning, upon reading his copy phoned me and made the laughing comment that it was the best judgment I had ever written.

It now became necessary to try to hold our position as an appeal was launched immediately.

While these events were taking place it had become necessary for me to 
commence a third action in our Supreme Court seeking an injunction to protect our leases because of the determination notices that had been served on my clients. On the 1st of February, 1951, before my meetings with Chief Justice Howson described above, I had launched an action for a declaration that my clients were not in default under the leases, for relief against forfeiture in the alternative, and for an injunction restraining the lessor Mike Szpilak from in any way disposing of the lease or interfering with our operations. In support of the application for an injunction I filed my own affidavit recounting all that we had done to live up to our agreement, the delay in getting judgment, and how we were preparing to drill the well pursuant to Chief Justice O'Connor's directives.

Justice H. H. Parlee signed the requested injunction Order on February 2,1951 . Like the little boy at the dike, I now hoped I had plugged all holes in our proceedings. It should be mentioned here that before going to Justice Parlee I had made a special trip into the country over extremely icy roads to try to negotiate an extension under the lease but the land owner turned me down.

As of this point in time therefore we had reached the position where:

(1) My clients now had a favourable judgment from Howson C.J. giving us back the three remaining drilling sites but this was under appeal.

(2) The original Wakefield action on their lien was temporarily stopped with production from the one well being accumulated in trust under the receivership.

(3) Our leases were protected by the Parlee injunction.

(4) The Clerk of the Court was busy drilling for oil and hoping to find it.

I now had to clear the decks with respect to the three remaining drill sites in the event the Clerk found oil. The Wakefield lien had been filed against all the land. Their solicitor, G. M. Peacock, Q.C., took the position that they were entitled to so file. I argued that they were misusing the power to file a lien, that they had a contract to drill one well on one site and that was where their lien should lie, and that the receivership would eventually collect enough to pay them.

Because of this deadlock, my people went back to Court again. An application came on before Mr. Justice C. C. McLaurin, as he then was, and with his usual flair he took the practical approach and removed the liens from our remaining legal subdivisions. An appeal was eventually filed by Mr. Peacock, but before it was filed, I had acted upon the McLaurin order and removed the liens from the titles at the Land Titles office. The appeal was never proceeded with.

We were now ready for production if it came.

Meanwhile Mr. Manning and I went back to Chief Justice O'Connor and a further order was obtained permitting the Clerk to drill a second well so as to protect the leases while the appeal went ahead.

\section{THE APPEALS-OIL CITY v. AMERICAN LEDUC}

At the opening of the next sitting of the Appeal Court, Ted Manning made a special application to introduce new evidence as is permitted under the Alberta Rules. His purpose was to show that Duncan A. Campbell had done all he could to make a good well out of a bad situation and had a special expertise which should enable Oil City to get relief. The 
Court, after some debate, during which Justice Frank Ford was vehement in his opposition to the motion, finally gave the leave requested but gave me the same privilege. This, as it turned out, was a real break for our side as we could now bring in all of the circumstances concerning how we had arranged to drill the next two wells and how Mr. Manning's clients had not assisted in any way. I do believe that, particularly when the case eventually ended up in Ottawa, this additional material made the case for us, particularly on the question of whether there should be relief against forfeiture.

On the hearing before the Court of Appeal, which took place on the 9, 10 and 11 of May, 1951, we had the full Court as it then was; namely: Chief Justice G. B. O'Connor, and Frank Ford, W. A. Macdonald, H. H. Parlee and Clinton J. Ford J.J. The attitude of the Court, particularly Justice Clinton J. Ford, seemed to be against me but when the judgment, which was reserved, was finally pronounced, it was unanimously in our favour.

The judgment of the Court was that the determination was valid. The question of relief against forfeiture was then discussed and some of the reasoning of Clinton J. Ford J.J. is I think worth quoting, showing as it did the Court's approach to a new field of jurisprudence-namely the oil business:

In the present case, the question is not one of relief for money paid, but of granting further time to drill where time is of the essence of the contract; and the principal thing or object was to explore the oil potentialities of the leases. It may well be said that the breach goes to the root of the contract.

As stated, the learned Trial Judge refused to grant relief. In his judgment he quotes extensively from "Thornton Oil and Gas", 5th Ed. The quotations are illuminative of the attitude on the question of relief from forfeiture of the Courts of the United States that have had to the present time a much wider experience than the courts of Canada in dealing with oil-drilling contracts and the problems arising in the development of oil fields and production of oil.

It is my opinion that the quotations, as well as others I have perused, support the view that the facts and circumstances of each case must be considered in the light of the object sought to be achieved by the parties to the contract; and having regard, also, to the nature of the oil production business with pressure being constantly exerted in pushing forward oil drilling operations.

In the present case the plaintiff company defaulted in what I consider to be an essential obligation of the agreement. The learned Trial Judge in refusing to grant relief from such failure cannot be said to have transgressed any principle of equity. He placed considerable emphasis on the evident lack of financial ability on the part of the plaintiffs to carry out their obligations. No proposal was placed before him by them to grant a reasonable period of time within which to commence drilling, and, in my opinion, that was when such suggestion or proposal should have been made; since, as I have intimated, in the nature of the business of drilling for oil, time is an important consideration, and especially where, as here, the several leases required drilling to be commenced within fixed periods of time.

The material permitted to be filed at the hearing of the appeal shows that the situation has deteriorated in respect of the grant of further time to the plaintiff; and this applies also to their financial ability to carry out the agreement.

This Division must take a realistic view of all the circumstances when asked to do equity. A well on Legal Subdivision 1, and another on Number 2, are now in course of drilling by or on behalf of the defendant companies under interlocutory Orders of the Court, granted during the interval that has elapsed since the trial, permitting them to do 80 in order that each of these leases might not be lost. The money for each well has been furnished by them; that for the well on Legal Subdivision 1, the well in respect of which the plaintiff company defaulted, is the sum of $\$ 37,500.00$ furnished by the defendant companies for the plaintiff company to drill it; and this money is not now available to the plaintiffs.

Another circumstance which, in my opinion, should be considered, is that in this, still a 
wildcat field, no certain valuable rights, but rather somewhat speculative rights, of property are at stake; and, also, that the plaintiffs retain under the agreement all their rights in the commercial well drilled on Legal Subdivision 7.

In this situation, I would consider that the Court should let the legal consequences of default determine the result, and would dismiss the appeal with costs.8

Our opposition immediately started the machinery in motion for an appeal to the Supreme Court of Canada. During this interim period our Clerk of the Court and his engineer were still heavily engaged in drilling for oil.

The Clerk's first well was still in difficulties with another "fishing" job but the second well was brought in as a producer. My client, Alvin Davis, and I drove down for the occasion and I took some pictures to record the event.

Mr. Davis asked if he could go with me to the Supreme Court. I said 'of course'. We had a most interesting trip together. His first to Ottawa and my first appearance before what had now become Canada's highest Court. In those days it was quite a trip, all night on a noisy North Star. By the time we hit Winnipeg we became stormbound, but finally after several hours of delay we arrived at the Capital City.

My client was quite a sensation wherever he went. Oil was still a novelty and still news in Canada. He was a big man and he had acquired a large white stetson with a small oil derrick affixed in the hat band. Wherever he went in Ottawa he was spotted as a Westerner. He enjoyed every minute of it.

As this was one of the first cases involving oil since the Leduc discovery to find its way to the Supreme Court of Canada we were given a bench of seven: Kerwin, Taschereau, Kellock, Estey, Locke, Cartwright and Fauteaux J.J.

In the result "my judgment" was upheld by the unanimous judgment of the Court. It was not without some embarassing moments however. Oil City had pled a different date as to when the well had begun to produce commercially than what we had pled. The evidence supported their date and that date fitted in better in the end result with our position. Mr. Manning argued that we were stuck with our pleadings. It is not without interest that when I asked to amend my pleadings, I was afforded this opportunity-at the highest level.

Again, as argument progressed, Mr. Justice Kellock asked me to explain how I accounted for certain facts being referred to by Chief Justice Howson in his judgment when they were not in the evidence. I answered that both Mr. Manning and I had been living with the case for some time and that with so many motions and other applications these facts must have accidentally slipped in in my written argument and picked up by the Chief Justice. Kellock snapped back: "Did you say living with the case or off it?" Little did he know that it did not necessarily follow that a lawyer representing an oil company always had to have a wealthy client.

In due course the Supreme Court Judgment came out and fortunately in favour of my clients. 9 The three remaining legal subdivisions were now properly my client's. This meant, of course, that they, through the Clerk, had been drilling on their own land all the time. Their wells produced for

8. Oil City Petroleums (Leduc) Ltd. et al. v. American Leduc Petroleums Ltd. et al. (1951) 2 W.W.R. (N.S.) 371.

9. Oil City Petroleums (Leduc) Ltd. et al. v. American Leduc Petroleums Ltd. et al. (1852) 3 D.L.R. 677. 
a while but eventually ceased to produce. Not a very happy result. In the present narrative we have no further interest in these wells but must now bo back to see what was happening in respect to Oil City No. 1 and the receivership.

\section{THE EARL F. WAKEFIELD ACTION IS REVIVED}

All the while we had been peregrinating our way to the Supreme Court of Canada in the Oil City case, the Wakefield case was in a state of suspense, but with the money rolling in to the Receiver's hands. The Oil City No. 1 well stopped producing before it had supplied enough to cover all claims. By now there was some $\$ 70,000.00$ so the time had come to find out who had first claim on it. Wakefield's counsel claimed priority under its lien for full payment including penalties and interest. Oil City took the position their claim was far too high. My people agreed with Oil City and also argued that in any event their lien did not cover our share of the production and could in no way protect a claim for penalties.

A trial date was fixed and it was agreed by all counsel that Chief Justice McLaurin (as he now was) would be a good man to hear the case because he understood the oil business. A firm date was obtained for trial and the parties collected together, not only clients, but expert witnesses of all types-drillers, engineers, geologists.

A pre-trial conference was first held. Ted Manning and I were there for our same clients. In the preliminary conference with Chief Justice McLaurin we casually mentioned that although there would be legal issues on such things as penalties, the main fight would be the value of the 2,570 feet of hole drilled by Wakefield.

I had to argue a case in Ottawa at the time fixed for trial, so my partner Vince Reynolds took my place at the trial. Since we expected Ted Manning to carry the load for the defence, Mr. Reynolds was expected to support our old enemy this time, and then if necessary also argue against penalties. Wakefield was represented by H. G. Nolan, Q.C. (later a Justice of the Supreme Court of Canada), J. H. Laycraft (now a Justice of the Supreme Court of Alberta) and G. M. Peacock, Q.C.

When the case opened before the Chief Justice in Edmonton the record shows Mr. Nolan saying "My Lord!" at which point the Chief Justice apparently went off the record and remarked that:

Morrow has said this is essentially a problem of how much. You fellows go on out and agree to all the other facts and I will then tell you how much this many feet is worth.

Surprising as it may be, the lawyers all agreed to this proposal. After several hours of heated discussion they arrived at an agreement as to the facts and went before the Chief Justice the next morning. He read them over and then spoke to the following effect:

Last night I had dinner with two oil drillers and they tell me that 2,500 feet at Leduc is worth $\$ 30,000.00$.

And so the judgment became $\$ 30,000.00$.

Upon my return, when I heard this, I was aghast. I refused to accept the judgment and insisted on going back before the Chief Justice. He heard us again, his judgment was reaffirmed, but at least a few minor details relating to the liens were cleared up at this time.

Manning and I then went to the Appeal Court. Our abstract showed that the Wakefield Mechanics Lien had not been renewed, as called for 
under the statute. This had not been filed at the trial because of the manner in which the case had gone. We filed it before the Appeal Court.

By the time the appeal came on the roll call of counsel had changed. Nolan, by now appointed to the Supreme Court of Canada had been replaced by J. V. H. Milvain, Q.C. (now Chief Justice of the Trial Division of the Supreme Court of Alberta) and J. H. (Herb) Laycraft. R. A. (Ross) MacKimmie, Q.C. was brought in on their side as extra counsel to protect the law firm, he representing their insurers-brought about by our submission that the lien had expired for non-renewal.

The Appeal Court was interested in the case and took great care to draw out argument on all issues. At one point Justice M. M. Porter suggested that there had really been no trial and they should send the whole thing back for re-trial. Val Milvain and Herb Laycraft and of course Ross MacKimmie were averse to this as it would permit failure to revive the lien to be brought out in a more direct manner.

It was decided to continue to hear it as an appeal. In the end result we, the appellants, succeeded in upsetting the trial verdict. There were two judgments pronounced on June 25, 1957. Justice Boyd McBride supported by Justice $H$. G. Johnston had accepted my argument that the sections under the Mechanics Lien Act upon which the trial judge was operating presupposed the existence of a valid lien, the lien had been allowed to die by failure to renew. The claimant could, however, get personal judgment for the amount of its claim.

To reach this conclusion McBride had accepted my argument based on Globe Sugar Refining Co. v. Port and Harbours of Greenook Trustees. ${ }^{\mathrm{a}}$ This was to the effect that a statutory provision should not be ignored by an appeal court even though it may not have been introduced at the trial level. What I hadn't realized at the time but learned of later-Justice McBride had been a university student in Glasgow when this case was before the British courts-so I had hit a very sympathetic ear.

The second judgment, Justice M. M. Porter, (concurred in by Ford C.J.A. and MacDonald J.A.) went on the narrow ground that the work was not done at the request of anyone who had an estate or interest in the land at the time it was commenced, nor was it done for anyone who had an interest in the oil and gas in the ground.

In the result our appeal was allowed by setting aside the lien but personal judgment against Oil City was given in the sum of $\$ 51,670.62 .{ }^{10}$

This was great but there was still one more Court to meet. By this time, my original client in these proceedings, Alvin M. Davis of Leduc had acquired control of Ponoka-Calmar and must have had a great deal of his own money invested in the company. I had faith in our case but I went to great length to explain how cases can be lost, how oil wells can go sour, and how he should hedge by selling some of his shares, but he was adamant. He had complete faith in the company-and in the oil. And I suspect, too much faith in his counsel. In passing I must mention that when the whole thing was over Mr. Davis suffered heavy financial loss. Law suits are great to win but can be devastating if lost.

In due course we arrived at Ottawa to argue the case before the Supreme Court. The argument in that Court, which took two days, began on February 5, 1958, which should have been a good omen for me as that 
is my birthday, but as events transpired it would require more than a birthday to get a favourable verdict. Justice Nolan by now had died, having been a member of Canada's highest Court for less than a year. The Court this time was Kerwin C.J., Rand, Locke, Fauteaux (later to become Chief Justice) and Abbott J.J.

It soon became apparent that our side was not popular in this Court. By the second day, Justice Locke was particularly hard on me, boring in on every point. Judgment was reserved but I did not think it would be long until the bad news would come.

I remember pondering the whole thing over during the plane ride back. We would lose, what then? What could be done to salvage something for my clients? I was especially concerned about Mr. Davis and his heavy commitment. And I was professionally concerned as I was certain that I was right.

Anyway, by the time I was landing at the Edmonton International Airport I was asking myself if by chance our case was old enough to be appealable to the Privy Council.

The next day at the office I checked it out. The Supreme Court Act had been amended. (supra). By this amending statute the Supreme Court of Canada had become the "exclusive ultimate" appeal Court in Canada and its judgment "shall, in all cases, be final and conclusive." (s. 3). The saving clause that I found was Section 7. It said:

7. Notwithstanding anything in Section 3 of this Act, an appeal from or in respect of a judgment pronounced in

(a) a judicial proceeding that was commenced prior to the coming into force of this Act, or . . . lies or may be brought as if the statute had not been enacted.

Our' Statement of Claim was issued December 5, 1949. The above amendment had been proclaimed on December 23, 1949. By these. few days history was to allow my side another chance.

In a matter of a few days I had contacted solicitors in London, the old and respected firm of Charles Russell \& Co. who had handled appeals from Canada for as long as Canada had been a Dominion. They sent me forms, they told me what I had to do, and I had copies of the nonfamiliar Privy Council Rules and Procedures. All was ready.

On April 22, 1958 the expected judgment came out-against us. The Court took a pretty straightforward approach. A lien had subsisted when the receivership had been taken out, while the lien had ceased to exist the lien had in effect become transferred as a charge on the monies protected by the receivership order. To arrive at some of the factual positions necessary to take this position inferences were made from the admitted facts agreed to before Chief Justice McLauren and from the pleadings. This latter aspect is clear from the remarks of Justice Locke found at pages 375 and 376 of the report. Kerwin C.J. and Fauteaux concurred in these conclusions. All of the learned Justices agreed with Justice Rand's conclusions in respect to the legal position taken. ${ }^{11}$

In what must have been almost the speediest attempt to appeal to the Privy Council in history, I was on my way almost the next day. Because the appeal was from the Supreme Court of Canada rather than from a Provincial Appeal Court, leave to appeal had to be first obtained by petition. 
My clients had already instructed me to attempt one more appeal. To them at this point it was the only hope of obtaining some return on their initial investment. American Leduc was able to pay its share of the expenses but Ponoka-Calmar could only agree to pay me out of future revenue if and when received. By now I was in so deep-from a "feeearned" basis-that I figured I might as well see it through. By the time I had made two trips to London, one for the petition for leave to appeal and one for the actual appeal, and had paid my London agents in full, I was personally down to the tune of $\$ 7,000.00$. My coffee remarks had come home to roost. I could ill afford to continue but could I afford to stopparticularly as I was confident of the outcome? Surely, after all a British Court would take the same line as Justice McBride.

And so the decision to go to the foot of the Throne was taken. My opposition had to oppose me but the following passages from Ross MacKimmie's letter, written at the time, reflects their thinking:

I have your letter of May 7th and might say I was somewhat stunned by the fact this was really going to the Privy Council. I only hope my luck holds out and that my clients will continue to retain me when the matter is argued, but I have fears they will decide it is much cheaper to hire someone in London to do this chore. It would be delightful to go and I sincerely hope that Brother Milvain will succeed in his present intention of insisting that $I$ attend in London with him.

As this was to be in a new Court I requested Russell \& Co. to obtain a counsel for me, experienced in Privy Council practice. They recommended Godfrey Le Quesne. ${ }^{12} \mathrm{He}$ was and is a specialist in Privy Council cases. It was an excellent choice. No one could have had better advice and support.

Our Petition was formally filed on July 23, 1958. Eventually the date for hearing was settled-October 20,1958. Mr. Le Quesne and Cyril Russell the solicitor instructing him on my behalf, gave as their opinion that while they thought I had a good case in law, that to get leave at this time would be an uphill battle. They reasoned that since the Government of Canada had abolished appeals almost ten years earlier that the Judicial Committee might be reluctant to interfere with declared Canadian public policy and so we would have an uphill burden. Alarmed by this, and aware that mechanics' lien legislation was an American rather than a British concept of law I decided to make the application myself.

Eventually the day arrived for my departure. I had booked passage on Air Canada to Montreal and B.O.A.C. to London. While passing over Winnipeg, although I did not know it at the time, B.O.A.C. had gone on strike. On landing in Montreal I was placed into a real dilemma until I found that my ever-alert wife, Genevieve, upon hearing of the strike, had already been busy and had me booked on a different airline. My trip to London went on uninterrupted therefore.

The Savoy Hotel had been recommended by our agents as close to No. 3 Downing Street (the Court room used by the Privy Council) and equally close to the Inns of Court where Mr. Le Quesne had his chambers. It was of course an excellent choice as the hotel is without a parallel in its reputation for good service and in its historical atmosphere. Also as I made my daily trips to and from the Inns of Court and to No. 3 Downing, I was able to in my own romantic mind's eye relive the hundreds of years of legal history. Another "Colonial lawyer" was winding through the narrow streets as 80 many of his predecessors in history had also done. 
The Charles Russell \& Co. office was out of Charles Dickens. Located at 37 Norfolk Street, Strand, and fronted by leaded windows, it was everything a person such as myself expected the office of a firm of British solicitors to be. Old and ancient furniture but not shoddy, more in the style of antiques. An air of tranquillity but behind it all, a feeling of unobtrusive efficiency. From there a clerk took me to the office of Mr. Le Quesne in the Inns where I was placed in his own office, looking through casement windows down over the gardens towards the embankment where the War of the Roses is supposed to have started. Suffice to say I was absorbing the historic atmosphere every moment as I prepared my application. During my stay Godfrey arranged for me to have lunch at his Inn-memorable in itself.

Finally the day came.

The final preliminaries had been a visit by me to hear an application being argued before the Privy Council from one of the colonies, and finally my trip to the famous Ede \& Ravenscroft, Law, Wig and Robe Makers, 93/4 Chancery Lane, for my wig.

I enjoyed every moment at Ede \& Ravenscroft. Once a suitable wig was fitted I had to sign the book recording my receipt of it. I don't know how far back the book went, suffice to say that in the few moments I had to turn back pages I saw names of counsel from all parts of the Commonwealth, names lawyers become familiar with as the law reports are read. On a shelf above me were the canisters of wig cases-one of the ones I noticed had the name "M'Naghten".

With trepidation in my heart I accompanied Le Quesne and Russell and their Clerk to the Court Room. We had to await disposition of a petition for leave to appeal from the Province of Quebec. ${ }^{13}$ It was turned down. Then came my turn.

When our time came to enter, we were lined up in order of senioritymyself, my junior Mr. Le Quesne, Cyril Russell and his Clerk, and proceeded in from the far left to take up seats on what would be the right, looking from the direction of the Lords Justices. My opposition, W. Percy Grieve, of London, followed by his retinue of solicitor and clerk came in from the opposite side in the same manner.

The members of the Judicial Committee sit along one side of a halfmoon shaped table dressed in business suits. Counsel as his time comes steps up to a small raised platform positioned on the opposite side of this table. As he leans on the lectern to address them he can almost reach each member. Your books are laid out on a special counter directly behind you.

My court was made up of five law lords: Lord Somervell, Lord Reid, Lord Tucker and Lord Denning with Viscount Simonds presiding. The hearing started at 11:00 a.m. and concluded at 12:30 p.m. on October 20, 1958.

I of course led off. After about a half hour and before I had completed my submission, Viscount Simonds, much to my surprise, asked me to sit down. He explained that I was not being cut off but that I had made out a prima facie case and they now wanted to hear from opposing counsel.

Mr. Grieve now began his argument. After a short time he seemed to be getting into trouble. Godfrey Le Quesne leaned over to me and 
whispered to watch what was to come. It was a delight to observe. By careful questions, the members of the Committee worked Grieve into a corner where he was no longer arguing whether there was an arguable appeal but was actually trying to argue the merits of the appeal. This was the end. Viscount Simonds then turned to me and pronounced that my petition had been granted. I jumped up and asked that leave be extended to the second point which I had not yet reached in my submission. They agreed. And so we were on our way.

It was a pretty excited lawyer that worked his way out of the court room that day. Just as Godfrey and I reached the robing room there was a great blare of trumpets and the clatter and roll of a carriage. On looking outside one saw the Queen and the President of Germany ride by in her state carriage. It was truly an exciting moment.

I cabled the good news to my clients and to my family and then headed home to prepare for the next and final round. On my return flight the Pan American Stratocruiser in which I was flying (B.O.A.C. being still on strike) lost an engine halfway over the Atlantic, adding some further flavour to an already exciting trip.

Eventually after my return to Edmonton I received a copy of the formal order granting leave.

The inscription at the top was as follows:

At the Court at Buckingham Palace

The 21st day of November, 1958

Present

The Queen's Most Excellent Majesty

There then follows a recital describing the petition and judgment and finally the concluding two paragraphs:

HER MAJESTY having taken the said Report into consideration was pleased by and with the advice of Her Privy Council to approve thereof and to order as it is hereby ordered that the same be punctually observed obeyed and carried into execution.

Whereof the Governor-General or Officer administering the Government of Canada for the time being and all other persons whom it may concern are to take notice and govern themselves accordingly.

We had truly gone to the foot of the throne.

It was next July before the appeal itself could be heard. Finally the day came to leave for London. B.O.A.C. were boosting their Comet Jet flight so I booked our trip with them. This time I arranged for my wife Genevieve to go along with me. Also, knowing there would never be another opportunity, I arranged for Bill Stevenson (now Judge Stevenson of the District Court of Alberta) of the firm to act as my junior along with Mr. Le Quesne. Bill was such a great student of law I felt it only right that he have the opportunity. Of course his expenses would have to come out of my fees if I ever got any, but it would be worth it. I have never regretted this decision. Mr. Stevenson has developed, predictably, into one of the best in his profession. No senior ever had better support that I had in Bill. I should observe in passing, though, that the English bar found it almost unbelievable that a lawyer of one year's standing should be permitted to appear before the Privy Council. Val Milvain seems to have had the same idea as myself, as he brought Herb Laycraft along too. Mr. Laycraft was, of course, top counsel as well. The Comet trip was a smooth one and before we knew it we were in the busy London airport and weaving our way through the bustling London traffic to the Savoy. 
The next few days were busy days and hot days. Busy as Godfrey, Bill and I prepared our case and discussed the strategy to follow. Hot ones as we had picked what the newspapers were to describe as record hot weather for London. One day while arguing the case the outside temperature reached $94^{\circ} \mathrm{F}$.

We used the library of the Inns of Court for our preparation. In no time I was a regular pedestrian from the hotel to the library, umbrella in hand (my burberry was stolen from the library to the complete embarrassment of my English brothers).

In our off hours we had a delightful visit with Mr. Butler and his sister. Mr. Butler was one of the senior partners of Charles Russell \& Co. and a man of great professional experience as well as tremendous personal charm. We also attended a reception put on by Canada's then Trade Commissioner Colonel Drew. On July 1 we were invited to a Dominion Day celebration which was the highlight for my wife, as the honourary guest, the Queen Mother, singled her out for a short discussion. The British certainly do know how to entertain and, shall we say, put on a show.

Finally the day for battle arrived-July 7,1959 . We completed argument July 9. This time I had with me, J. G. Le Quesne, W. A. Stevenson, Cryill Russell as solicitor, and his clerk. The opposition consisted of J. V. H. Milvain, Q.C.; R. A. MacKimmie, Q.C.; W. Percy Grieve; David Smout and J. H. Laycraft. This time the Court was made up of Viscount Simonds, Lord Reid, Lord Radcliffe, Lord Tucker and Lord Denning.

Our argument emphasized two main points: (1) There never was a valid lien, (2) if there ever was a lien, it was allowed to lapse, and accordingly Wakefield was not entitled to priority in payment over us. Le Quesne followed me in argument. Then came Milvain followed by MacKimmie. I took the reply.

If my experience in this Court is typical of the Judicial Committee's general approach to appeals then there can be little complaint by counsel or litigant. Presumably we had come a long distance to be heard and we were heard-patiently and earnestly. I had difficulty with their Lordships' accents and Viscount Simonds said he had trouble with my Canadian accent. By the end of the first day it must have become apparent to their Lordships that the heat in the court room combined with the humidity and my lack of experience with a heavy wig, was causing me no end of discomfort.

Accordingly Viscount Simonds stated that we could doff our wigs for the remainder of the appeal. So the last case became a first caseaccording to the newspaper reports it was the first time that counsel had been permitted this special dispensation.

As the case progressed I had the feeling that Lord Denning, at least, was my way, while Lord Tucker was against me. By rebuttal time my assessment was that the members were evenly divided and Lord Reid, who asked a series of pointed questions, had to be satisfied. I did my best, but as we eventually found out, I was not persuasive enough.

At the conclusion of the case we could all sense a feeling of sadnessthis was undoubtedly to be the last appearance of counsel from Canada. Viscount Simonds remarked that almost ten years before they had had a ceremony marking what was thought to be the last case and yet here we 
were again. But as he said, they didn't propose a second celebration in case they might be wrong again. The air of sadness certainly affected our English brothers who undoubtedly hated to see the Canadian cases disappearing from their field.

As we went out, my bunch had the two Court Orderlies, Glenwright and Stone, join us on the lawn for picture taking. They were a bit timid but finally we persuaded them to pose with us.

Later that afternoon all sides partook of gin and tonic in the American bar at the Savoy. Later each side had their separate celebrations. Ours was a memorable dinner and party at the home of Cyril Russell.

And so the once-in-a-lifetime case was over, except for the verdict and whatever mopping up that verdict may require.

Finally on October 7,1959 , the bad news came. Our approach to the foot of the throne had failed.

In setting forth the conclusion of the Judicial Committee, Viscount Simonds got around my argument regarding the failure to refile the lien quite nicely. At page 35 of the official report ${ }^{14}$ this is what he states:

It further appears to their Lordships that any doubt that might otherwise exist is set at rest by the provisions of section 37 of the Act, which provides for the application of moneys 'realised by proceedings under this Act.' It is clear that the moneys paid into court or into a special fund by the receiver are moneys 'realised by proceedings under this Act.' If 80, they must be applied and distributed in the prescribed order to the persons therein named. But it was urged that the lienholders therein mentioned meant only those persons who had subsisting liens on the land at the date of distribution. This contention cannot be accepted. For the land subject to the lien had been sold and under section 26(2) the lienholder was relegated to the claim to a lien 'to the same extent as if the money was realised by a sale of the property in an action to enforce the claim.' It follows that the lienholders mentioned in Section 37 are those persons who had at the time of the sale a lien on the property sold and brought their action to enforce it. The only consistent interpretation of the Act is to treat the proceeds of sale of oil and gas realised by the receiver in the same way as the proceeds of sale of the land itself. This may be described as creating a charge on the fund; but equally it is the method which a court administering a fund under its control must employ in order to preserve and give effect to the rights of the parties, and it is that principle that is embodied in section 37 . For these reasons, their Lordships are of the opinion that the judgment of the Supreme Court of Canada was correct. They will therefore humbly advise Her Majesty that this appeal should be dismissed. The appellants must pay the costs of the appeal.

Once again the formal document was entitled "At the Court at Buckingham Palace" but alas this time the Queen's justice was disposed towards our opponents.

Our main attention now was to wind up affairs and see if anything could be salvaged. Several applications had to be made, most of them to Chief Justice McLaurin.

On one of these, I pointed out how I had attempted to protect the general creditors albeit unsuccessfully. With his usual generosity to counsel he directed that I should be considered as having a prior charge on any surplus funds left after the lien was satisfied for my actual disbursements but no fees. These disbursements amounted to $\$ 7,942.91$. This was a great relief to me. It is true, I had worked hard for no fee-to have had the one chance to appear before the Judicial Committee would have to be my fee. I think I was well paid.

Finally Chief Justice McLaurin awarded interest to the lienholder. One

14. Ponoka.Calmar Oils Ltd. et al. v. Earl F. Wakefield Co. et al., [1960] A.C. 18, [1959] 3 W.L.R. 631, (1959) 29 W.W.R. 638 . 
final appeal was taken from this award. The Alberta Court of Appeal judgment in the final judgment rendered between the parties was pronounced on April 4, 1960 and is found in [1960] 31 W.W.R. 376. Ironically enough, in theory, there could have been an appeal again to the Privy Council, but like Jarndyce v. Jarndyce in Bleak House-the proceedings had to come to an end as the funds had run out by now.

Once, just once, in my lifetime as a lawyer I was able to take a case to the foot of the throne. It was a tremendous experience even if I am unable to claim success. 